\title{
UPAYA MENINGKATKAN HASIL BELAJAR EKONOMI PESERTA DIDIK DENGAN MENERAPKAN MODEL PEMBELAJARAN THINK PAIR SHARE DI KELAS X-2 PADA SMA MUHAMMADIYAH PALANGKA RAYA
}

\author{
Oleh : Ayu* Sonedi**
}

\begin{abstract}
ABSTRAK
Penelitian ini bertujuan untuk: (1) mengetahui aktivitas belajar peserta didik saat proses pembelajaran Ekonomi dengan menggunakan Model Pembelajaran Think Pair Share (TPS), (2) mengetahui peningkatan hasil belajar Ekonomi peserta didik kelas X-2 dengan menggunakan Model Pembelajaran Think Pair Share (TPS) di SMA Muhammadiyah 1 Palangka Raya.

Subjek dalam penelitian ini adalah seluruh peserta didik kelas X-2 SMA Muhammadiyah 1 Palangka Raya yang berjumlah 22 orang peserta didik. Jenis penelitian ini yang digunakan adalah Penelitian Tindakan Kelas (PTK) dengan Model Pembelajaran Think Pair Share (TPS).

Hasil penelitian menunjukkan bahwa: (1) Aktivitas belajar peserta didik dengan menggunakan Model Pembelajaran Think Pair Share (TPS) lebih baik dan meningkat, (2) Ada peningkatan hasil belajar Ekonomi pada peserta didik dengan menggunakan Model Pembelajaran Think Pair Share (TPS). Pada siklus I hasil Pre-Test ada 2 orang peserta didik yang tuntas $9,99 \%$ dan hasil Post-Test 11 orang peserta didik yang tuntas 55\% dan pada siklus II hasil Post-Test ada 18 orang peserta didik yang tuntas 90\%. Ini berarti dengan menggunakan Model Pembelajaran Think Pair Share (TPS) dapat meningkatkan hasil belajar peserta didik kelas X-2 SMA Muhammadiyah 1 Palangka Raya.
\end{abstract}

Kata kunci: Hasil belajar Ekonomi, Model Pembelajaran Think Pair Share (TPS)

\section{PENDAHULUAN}

Pelaksanaan pendidikan di Indonesia merupakan upaya yang terpadu dari lembaga-lembaga yang terkait guna mencapai tujuan pendidikan nasional. Sekolah merupakan lembaga pendidikan formal yang bertugas melaksanakan atau menyelenggarakan pendidikan dan pengajaran secara sistematis yang memungkinkan usaha mencapai tujuan pendidikan. Dalam keseluruhan proses pendidikan, kegiatan belajar mengajar merupakan kegiatan yang paling pokok. Fathurrohman (2007:8) mengemukakan bahwa: Hal ini berarti bahwa berhasil tidaknya pencapaian tujuan pendidikan banyak bergantung kepada bagaimana proses belajar mengajar yang dirancang dan dijalankan secara professional sehingga dapat dikatakan bahwa belajar mengajar tidak dapat disepelekan dan diabaikan dalam dunia pendidikan.

Jadi, dalam proses belajar mengajar guru tidak hanya sekedar menerangkan sejumlah materi pelajaran kepada peserta didik. Tetapi 
pembelajaran yang diharapkan terjadinya aktifitas belajar mengajar yang melibatkan seluruh aspek yang dimiliki oleh peserta didik, baik fisik maupun psikis. Sehingga peserta didik tidak berperan sebagai pendengar saja.

Terdapat berbagai macam model pembelajaran yang ditawarkan dan perlu dikembangkan di sekolah. Salah satunya adalah model pembelajaran kooperatif Think Pair Share (TPS) yang merupakan sebuah model pembelajaran yang dcetuskan oleh Frangklin Lyman dari Universitas Maryland yang dirancang untuk mempengaruhi pola interaksi siswa, dan "Merupakan suatu cara yang efektif untuk membuat variasi suasana pola diskusi kelas", Arends (Chichi, 2015:5). Karena model ini merupakan suatu pengajaran materi pelajaran dengan cara yang lebih menarik yaitu guru menyampaikan materi pelajaran lalu guru mengajukan suatu permasalahan sehingga peserta didik akan dibuat berpikir secara aktif dan kritis lalu peserta didik akan berpasangan dan menjelaskan di depan peserta didik yang lain tentang materi pelajaran yang akan dibahas sehingga, model pembelajaran ini mengajak peserta didik untuk berpikir, berpasangan dan berbagi.

Guru memiliki peran yang sangat penting untuk menciptakan kondisi pembelajaran yang efektif. Salah satu kompetensi professional yang harus dimiliki seorang guru adalah guru dapat memilih, mengembangkan dan menggunakan model pembelajaran.

Sedangkan peserta didik diharapkan mampu mengembangkan pola pemikirannya sehingga dapat berpikir secara aktif dan kritis dengan mempraktekkan maupun mengaplikasikan materi pelajaran yang telah disampaikan oleh guru.

Penelitian ini penting, karena model pembelajaran tipe Think Pair Share (TPS) memberikan kesempatan kepada peserta didik untuk bekerja sama dengan orang lain, sehingga dapat meningkatkan partisipasi aktif peserta didik. Disamping itu model pembelajaran seperti ini jarang digunakan di sekolah-sekolah tertentu.

Model pembelajaran pada hakekatnya merupakan salah satu bagan dari keseluruhan sistem belajar dan tidak dapat dipisahkan dari sistem lainnya. Perkembangan model pembelajaran dari waktu ke waktu terus mengalami perubahan. Modelmodel pembelajaran tradisional kini mulai ditinggalkan dan berganti dengan model yang lebih modern. Model pembelajaran merupakan suatu pendekatan yang digunakan dalam kegiatan pembelajaran.

Rusman (2012:132) berpendapat bahwa "Model pembelajaran adalah upaya mengimplementasikan rencana pembelajaran yang telah disusun dalam kegiatan nyata agar tujuan yang telah disusun dapat tercapai secara optimal". Sedangkan Eggen dan Kauchak (Trianto, 2013:22) mendefinisikan bahwa model pembelajaran memberikan kerangka dan arah bagi guru untuk mengajar.

Menurut Kardi dan Nur (Trianto, 2007:6) model pembelajaran mempunyai empat ciri khusus yang tidak dimiliki oleh strategi, metode 
atau prosedur. Ciri-ciri tersebut sebagai berikut:

1) Rasional teoretik yang disusun oleh para pencipta atau pengembangnya.

2) Landasan pemikirannya tentang apa dan bagaimana siswa belajar (tujuan pembelajaran yang akan dicapai).

3) Tingkah laku mengajar yang diperlukan agar model tersebut dapat dilaksanakan dengan berhasil.

4) Lingkungan belajar yang diperlukan agar tujuan pembelajaran itu dapat tercapai.

Model pembelajaran kooperatif Think Pair Share merupakan jenis pembelajaran kooperatif yang dirancang untuk mempengaruhi pola interaksi siswa. Pertama kali dikembangkan oleh Frank Lyman. Arends (Trianto, 2013:81) menyatakan bahwa:

Think Pair Share merupakan suatu cara yang efektif untuk membuat variasi suasana pola diskusi kelas. Dengan asumsi bahwa semua resitasi atau diskusi membutuhkan pengaturan untuk mengendalikan kelas secara keseluruhan dan prosedur yang digunakan dalam Think Pair Share dapat memberi waktu lebih banyak peserta didik untuk berpikir, untuk merespon dan saling membantu.

Menurut Wibowo (2013:47) Model pembelajaran Think Pair Share adalah "salah satu model pembelajaran yang memberi kesempatan kepada setiap siswa untuk meningkatkan partisipasi kepada orang lain". Sependapat dengan teori Lyman (Mursalin, 2012:4) mengemukakan bahwa:
Think Pair Share membantu para siswa untuk mengembangkan pemahaman konsep dan materi pelajaran, mengembangkan kemampuan untuk berbagi informasi dan menarik kesimpulan, serta mengembangkan kemampuan untuk mempertimbangkan nilai-nilai dari suatu materi pelajaran.

Think Pair Share yang dikembangkan oleh Frank Lyman dari Universitas Maryland yaitu bertujuan memperkenalkan peserta didik untuk berpikir sebelum berbagi diantara pasangan atau kelompoknya atau dengan seluruh anggota kelas sehingga peserta didik mampu dalam menguasai dan memahami materi pelajaran.

Berdasarkan paparan di atas tujuan penelitian ini adalah:

1. Untuk mengetahui peningkatan aktivitas peserta didik di kelas X-2 SMA Muhammadiyah 1 Palangka Raya pada saat pembelajaran Ekonomi dengan penerapan model pembelajaran Think Pair and Share.

2. Untuk mendeskripsikan ada tidaknya peningkatan hasil belajar peserta didik di kelas X-2 SMA Muhammadiyah 1 Palangka Raya pada pembelajaran Ekonomi dengan penerapan model pembelajaran Think Pair and Share.

\section{METODE PENELITIAN}

Adapun jenis penelitian yang digunakan dalam penelitian ini adalah 
Penelitian Tindakan Kelas (PTK) yang bertujuan untuk melakukan perbaikanperbaikan terhadap sistem, isi dan kompetensi atau situasi pembelajaran dengan menguji cobakan suatu ide kedalam praktik dan situasi yang nyata dalam proses belajar mengajar di kelas dengan harapan kegiatan tersebut dapat meningkatkan hasil proses belajar mengajar.

Menurut Kunandar (2012:45) "penelitian tindakan kelas (PTK) adalah penelitian tindakan yang dilakukan dengan tujuan memperbaiki mutu praktik pembelajaran di kelas". Penelitian ini berusaha menjawab permasalahan yang diajukan peneliti yaitu pembelajaran dengan penerapan model pembelajaran Think Pair Share (TPS) untuk meningkatkan hasil belajar Ekonomi materi Kebijakan Pemerintah dalam Bidang Ekonomi pada peserta didik kelas X-2 SMA Muhammadiyah 1 Palangkaraya tahun pelajaran 2015/2016.

Teknik pengumpulan data pada penelitian ini menggunakan observasi dan tes. Observasi dipergunakan untuk mengumpulkan data tentang aktivitas peserta didik dalam proses belajar dan peneliti dalam proses mengajar. Tes digunakan untuk mendapatkan data tentang hasil belajar peserta didik.

$$
\text { Data yang diperoleh }
$$
dikumpulkan dan diolah sedemikian rupa sehingga hasilnya dijadikan bahan untuk analisis. Data dalam penelitian ini memberikan gambaran mengenai hasil belajar dan keaktifan peserta didik dalam mengikuti pembelajaran Ekonomi dengan menggunakan model pembelajaran Think Pair Share (TPS).
Data yang dikumpulkan dari setiap kegiatan yang dilaksanakan dalam siklus PTK dianalisis secara deskriptif dengan menggunakan teknik persentase untuk melihat kecenderungan yang terjadi dalam pembelajaran. Data yang diperoleh melalui instrumen yang telah dikumpulkan sebelumnya diolah menjadi dua jenis data yaitu secara kuantitatif dan kualitatif.

\section{HASIL DAN PEMBAHASAN}

Berdasarkan perhitungan nilai rata-rata dan ketuntasan hasil belajar, didapat hasil belajar tes awal peserta didik kelas X-2 SMA Muhammadiyah 1 Palangka Raya didapat nilai rata-rata sebesar 27,86 dan ketuntasan belajar sebesar $9,09 \%$ yang termasuk dalam kriteria sangat kurang tercapai. Nilai rata-rata yang diperoleh peserta didik sebesar 27,68 masih belum memenuhi kriteria ketuntasan minimal 76 dannilai ketuntasan hasil belajar sebesar 9,09\% juga masih jauh dari kriteria ketuntasan klasikal 85\%. Sehingga pada tes awal dalam ketetapan tingkat ketercapaian keberhasilan pembelajaran belum memenuhi syarat ketuntasan belajar.

Data dari hasil dari pre test yang dilakukan pada saat pra siklus/pra tindakan terdapat 2 peserta didik yang mencapai kriteria ketuntasan minimal (KKM) yang sudah ditetapkan yaitu 76. Pada siklus I 20 peserta didik tersebut yang akan dijadikan fokus penelitan.

Skor aktivitas belajar peserta didik pada siklus I secara individual terdapat 11 orang peserta didik yang mendapat skor rata-rata 3 dan 9 orang 
yang mendapat skor rata-rata di bawah 3. Persentase dari skor rata-rata aktivitas peserta didik sebesar 60,64\%. Sehingga aktivitas peserta didik pada siklus I belum bisa dikatakan baik.

Sedangkan pada siklus II secara individual terdapat 18 peserta didik yang mendapat skor rata-rata 3 dan 2 orang peserta didik yang mendapat skor rata-rata di bawah 3. Persentase dari skor rata-rata aktivitas peserta didik secara keseluruhan pada siklus ke II adalah 66\%. Sehingga aktivitas peserta didik pada siklus II sudah dapat dikatakan baik.

Berarti peningkatan aktivitas belajar peserta didik seperti yang diungkapkan diatas sudah terpenuhi sesuai hipotesis penelitian yang menyatakan bahwa aktivitas belajar peserta didik saat proses pembelajaran Ekonomi dengan menggunakan model pembelajaran Think Pair Share (TPS) lebih baik.

Pada siklus I ada 11 orang peserta didik yang tuntas, dan saat pelaksanaan siklus II ada 18 peserta didik yang mencapai nilai ketuntasan minimum. Jumlah peserta didik yang tidak tuntas pada tes awal ada 20 orang, pada siklus I ada 9 orang dan pada siklus II ada 2 orang peserta didik yang tidak tuntas.

Dari hasil belajar tersebut maka dapat diketahui peningkatan sebelum dan setelah dilakukannya tindakan, hasil penelitian ini juga memperkuat bahwa model pembelajaran Think Pair Share dapat meningkatkan hasil belajar peserta didik

Dalam penelitian tersebut terdapat peningkatan hasil belajar IPA peserta didik setelah menerapkan model pembelajaran TPS (Think Pair Share). Hal ini dibuktikan dari hasil rata-rata belajar pre-test yaitu 74,6 ratarata post-test siklus I yaitu 84,6 dan pada rata-rata post test siklus II yaitu 89,3. Dan pada hasil ketuntasan belajar secara klasikal pre-test yaitu $60 \%$ atau 9 orang peserta didik tuntas belajar, pada post-test siklus I yaitu $67 \%$ atau 10 orang peserta didik tuntas belajar, dan pada post-test siklus II yaitu 93,3\% atau 14 orang peserta didik yang tuntas belajar.

\section{KESIMPULAN}

Berdasarkan hasil penelitian dan pembahasan pada BAB IV, maka dapat diambil kesimpulan sebagai berikut:

1. Ada peningkatan aktivitas peserta didik dalam pembelajaran Ekonomi dengan menggunakan Model Pembelajaran kelas X-2 SMA Muhammadiyah 1 Palangka Raya. Pada siklus I dapat diketahui perolehan hasil persentase aktivitas belajar peserta didik sebesar $60,46 \%$ dan rata-rata sebesar 2,98 atau terdapat 11 orang peserta didik yang memperoleh skor rata-rata 3 dan pada siklus II dapat diketahui perolehan hasil persentase aktivitas belajar peserta didik sebesar $66 \%$ dan rata-rata sebesar 3,3 atau terdapat 18 peserta didik yang memperoleh skor rata-rata 3.

2. Ada peningkatan hasil belajar Ekonomi setelah menggunakan Model Pembelajaran Think Pair Share (TPS) pada peserta didik 
kelas X-2 SMA Muhammadiyah 1 Palangka Raya. Pada pra siklus diketahui perolehan hasil persentase test awal yaitu 9,09\%, terdapat 2 orang peserta didik yang mencapai nilai ketuntasan minimum, dan 20 orang peserta didik dikategorikan tidak tuntas, nilai perolehan rata-rata pada tes awal (Pre Test) sebesar 44,22. Adapun perolehan pada siklus I jumlah persentase hasil belajar peserta didik mencapai $55 \%$ dengan 11 orang peserta didik dikategorikan tuntas, dan $45 \%$ atau 9 orang peserta didik dinyatakan tidak tuntas, dengan perolehan rata- rata sebesar 76 . Pada siklus II, perolehan hasil belajar peserta didik adalah $90 \%$ dengan 18 peserta didik dinyatakan tuntas dan $10 \%$ atau 2 orang peserta didik dikategorikan tidak tuntas, dengan perolehan nilai rata-rata sebesar 93,7 Ada peningkatan hasil belajar ekonomi dari Pre Test ke siklus I yaitu sebanyak 45,91\%, sedangkan dari siklus I ke siklus II ada peningkatan hasil belajar yaitu sebanyak 35\%. Ini dapat disimpulkan bahwa ada peningkatan hasil belajar dengan menggunakan Model Pembelajaran Think Pair Share (TPS) di SMA Muhammadiyah 1 Palangka Raya.
Kunandar. 2012. Langkah Mudah Penelitian Tindakan Sebaga Pengembangan Profesi Guru. Jakarta: Raja Grafindo Persada.

Mursalin, Kasman. 2012. Penerapan Model Pembelajaran Think Pair Share Untuk Meningkatkan Hasil Belajar Siswa Pada Materi Bentuk Muka Bumi dan Kegiatan Ekonomi. Gorontalo. UNG.

Rusman. 2011. Model-Model Pembelajaran Mengembangkan Profesionalisme Guru. Jakarta: Raja Grafindo Persada.

Trianto. 2013. Mendesain Model Pembelajaran Inovatif Progresif. Jakarta: Kencana Prenada Media Group.

\section{DAFTAR PUSTAKA}

Fathurahman dan Sutikno. 2007. Strategi Belajar dan Mengaja. Jakarta: Rineka Cipta. 